\title{
Mediação como método de resolução de conflitos escolares, da escola Nossa Senhora de Fátima ${ }^{1}$
}

\author{
Mediation as a method of resolving school conflicts, the Nossa Senhora \\ de Fátima school
}

\section{Mediación como método de resolución de conflictos escolares, de la escuela Nossa Senhora de Fátima}

\author{
Biembe Bakamba Médard² \\ http://orcid.org/0000-0001-6185-7313 \\ Miguel Ysrrael Ramirez-Sánchez ${ }^{3}$ \\ http://orcid.org/0000-0003-3045-5391
}

\begin{abstract}
Resumo: Este artigo tem em vista analisar a mediação escolar de conflitos e sua viabilidade na Escola da Nossa Senhora de Fátima (ENSF) na cidade da Beira em Moçambique. Nesta pesquisa a mediação escolar é concebida como um elemento importante da filosofia educativa e como uma oportunidade de formação pessoal e social para resolver os conflitos do dia-a-dia e promover uma cultura de paz. O estudo tem quatro objetivos específicos: a) identificar que tipo de conflitos ocorrem na ENSF; b) descobrir as fontes e os níveis de conflitos na ENSF; c) reconhecer a forma como são geridos conflitos na ENSF; e d) sugerir a mediação como um dos métodos de resolução de conflitos na ENSF. A conclusão deste estudo traduz-se em várias sugestões práticas, nomeadamente a criação e implementação de um Departamento de Serviços de Apoio ao Aluno (DSAA), como espaço de convívio, onde os alunos possam ter e sentir a liberdade de expressão para resolver as suas diferenças. Palavras-chave: Mediação escolar. Gestão de conflitos. Escola Nossa Senhora de Fátima. Cidade da Beira. Pesquisa em sala de aula.
\end{abstract}

Abstract: This article aims to analyze the school mediation of conflicts and their viability in the School of Our Lady of Fátima (ENSF) in the city of Beira in Mozambique. In this research, school mediation is conceived as an important element of educational philosophy and as an opportunity for personal and social formation to resolve day-to-day conflicts and promote a culture of peace. The study has four specific objectives: a) identify what kind

1 Trata-se de uma escola secundaria na cidade da Beira-Moçambique.

2 Bacharelado em Filosofia, Pós Graduação em Ensino a Distância Porto-Universidade Católica Portuguesa (2016), Mestre em Teologia Sistemática na Universidade Católica Portuguesa (2005), Doutorando na Universidade Internacional Ibero-americano: México (2013) Docente na Universidade Católica de Moçambique desde 2008.

E-mail: mbiembebakamba@yahoo.fr

3 Doutor em Educação com especialidade em pesquisa pela Universidad Internacional Iberoamericana (2017). Atualmente é professor investigador da Universidad Internacional Iberoamericana e Coordenador do Doutorado em Projetos em Língua Portuguesa.

Autor para correspondência via e-mail: miguelyramirez@hotmail.com 
of conflicts occur in the NSS; b) to discover the sources and levels of conflicts in the ENSF; c) recognize the way conflicts are managed in the ENSF; and d) suggest mediation as one of the conflict resolution methods in ENSF. The conclusion of this study is translated into several practical suggestions, namely the creation and implementation of a Student Support Services Department (DSAA), as a convivial space where students can have and feel the freedom of expression to solve their differences.

Keywords: School mediation. Conflict management. Nossa Senhora de Fátima school. City of Beira. Research in the classroom.

Resumen: Este artigo tiene como objetivo analizar la mediación escolar de conflictos y su viabilidad en la Escuela de Nossa Senhora de Fátima (ENSF) en la ciudad de Beira en Mozambique. En esta investigación la mediación escolar es concebida como un elemento importante de la filosofía educativa y como una oportunidad de formación personal y social para resolver los conflictos del día a día y promover una cultura de paz. El estudio tiene cuatro objetivos específicos: a) identificar qué tipo de conflictos ocurren en la ENSF; b) descubrir las fuentes y los niveles de conflictos en la ENSF; c) reconocer la forma como son generados los conflictos en la ENSF; e d) sugerir la mediación como uno de los métodos de resolución de conflictos en la ENSF. La conclusión de este estudio se traduce en varias sugerencias prácticas, a través de la creación e implementación de un Departamento de Servicios de Apoyo al Alumno (DSAA), como espacio de convivio, en donde los alumnos puedan tener y sentir la libertad de expresión para resolver sus diferencias.

Palabras clave: Mediación escolar. Gestión de conflictos. Escuela Nossa Senhora de Fátima. Ciudad de Beira. Investigación en el salón de clases.

\section{INTRODUÇÃO}

O ser humano é comunitário por essência. Esta comunidade se constrói através do esforço e contribuição de cada um em singular. Esta singularidade tem sentido no momento em que ela se abre para outro, ou seja, quando partilha a vida com outro. Se abrir, congregar ou viver com outro não é uma tarefa fácil dada a diversidade de características dos indivíduos, de cultura e de mentalidade. É dessa diversidade que surgem as situações de conflito, inerentes ao ser humano e vividas no quotidiano de formas muito variadas. A educação escolar não escapa a esta realidade.

A mediação escolar, método que se quer estudar nesta pesquisa inclui-se nos métodos extrajudiciais de solução de conflitos conhecidos. Esta técnica tem como objetivo restabelecer o diálogo entre pessoas envolvidas e a reconstrução da relação, com proposta de mudanças culturais e reconhecimento das diferenças. A mediação surge a qualquer momento onde se encontra uma comunidade humana. Nesta perspectiva, qualquer pessoa pratica a mediação em diferentes níveis. Neste sentido, a mediação faz uma análise da reconstrução crítica do conflito e valoriza todas suas dimensões. Dias (2010) sublinha que uma das caraterísticas mais importantes da mediação reside na reconstrução crítica do conflito.

A mediação realça-se, como constatam Correia e Caramelo (2010) da maneira como reduzir os conflitos na sociedade aos défices de comunicação entre as partes envolvidas em conflito ou entre estas e as instituições. Para compreender a mediação importa con- 
siderá-la não apenas como forma alternativa de resolução de conflitos, apesar que a sua compreensão tem a sua no conflito (NEVES, 2010).

Para Costa (2016), o conflito não é, neste caso, entendido como algo negativo a reprimir e a controlar. Essa conceição tradicional do conflito deu lugar a uma outra, a conceição crítica, segundo a qual o conflito pode ser considerado ou ser visto como um crescimento humano, uma oportunidade de mudança e de bem-estar das partes envolvidas no mesmo conflito. Por sua vez, o papel do mediador também não se circunscreve à resolução de conflitos.

Este artigo tem uma relevância social importante. O mundo em que vivemos está continuamente em mudança. Basta ver a televisão, ouvir a rádio, ler jornais para constatar a conflitualidade decorrente ou inerente a assuntos fortes no mundo contemporâneo como terrorismo, guerras civis, diversidade de culturas e multiculturalismo, imperialismo, globalização, internacionalismo, a influência dos media. Nestes conflitos e jogos de interesses, as crianças e os jovens são sempre os mais vulneráveis, sobretudo os refugiados, os pobres, os desamparados.

Interrogamo-nos, assim, se estes conflitos influenciam o sector educacional escolar e os alunos. Não estará a origem dos conflitos que se vivem nas escolas na vida social quotidiana? E os alunos não serão influenciados para imitar também o que se passa na vida social e familiar? Com que frequência ocorrem os conflitos escolares?

Parte-se do princípio de que gerir tais situações de maneira diferenciada é condição sine qua non e propõe-se que a metodologia da mediação escolar se torne a opção mais apropriada para gerir e administrar os diferentes conflitos escolares, dado que, através deste processo, a subjetividade envolvida nas situações de conflitos será explicitada quando as partes dialogam, aumentando assim a probabilidade de resultados construtivos para as partes envolvidas.

Em síntese, este artigo tem o intuito de contribuir para implantar a cultura da paz no ambiente escolar, visando estudar a mediação escolar, enquanto processos de sensibilização, capacitação e observação que ajuda a compreender as diferenças e o papel dos Educadores nesse processo de mediação. A educação escolar pode ajudar os alunos a crescer num ambiente de construir a paz, cultivar o diálogo, não só ao nível escolar, mas também em todo o contexto social, sobretudo num mundo como o atual, cheio de contradições, conflitos nacionais e internacionais. E segundo Correia e Caramelo (2010), para construir a paz precisa se de respeito mútuo, tomando em conta a diversidade cultural de cada povo e nação, valorizando o que positivo, colando a vida humana no centro de tudo e, a existência 
da mediação tem vindo a justificar-se e a legitimar-se através do seu papel na profilaxia do conflito.

Pretende-se compreender a forma como são geridos os conflitos nas escolas. Como refere Gonçalves (2014), o nosso mundo de hoje precisa se duma cultura de paz e pela cultura de paz assim como o peixe se sente à vontade vivendo na água. Todo ser humano que deseja viver em paz deve promover a cultura da paz. Neste sentido temos que lançar mão dos melhores meios de educação para a paz.

Face ao que fica dito, questionamo-nos: A mediação pode ser utilizada como um dos métodos de resolução de conflitos escolares na ENSF? Esta questão de base na nossa investigação tem subjacente o interesse em: Identificar a ocorrência de conflitos escolares na ENSF; Reconhecer as fontes e os níveis de conflitos escolares na ENSF; Descrever as formas de gestão de conflitos escolares usadas na ENSF; Sugerir a mediação como um dos métodos de resolução de conflitos escolares.

Este estudo tem como finalidade de analisar a mediação escolar pode ser usada como um dos métodos alternativo de resolução de conflitos da ENSF. O artigo visa, especificamente, identificar a ocorrência de conflitos na ENSF, reconhecer as fontes e os níveis de conflitos, descrever a forma como são geridos conflitos, sugerir a mediação como um dos métodos de resolução de conflitos na ENSF.

\section{FUNDAMENTO TEÓRICO}

\subsection{Esteira africana: resolução de conflitos escolares}

A esteira africana é um espaço que visa pacificar conflitos gerados para alguns membros da comunidade. No contexto africano, a esteira representa a cama, cadeira, um instrumento para sentar, dormir, um espaço do encontro com o outro, com a comunidade, um espaço de alegria, de pertença, de comunhão, ao mesmo de tempo de tristeza e colação. $O$ africano em geral, e o moçambicano em particular, tem sentido de pertença na comunidade. Esta comunidade tem o lugar do encontro na esteira onde se pratica a justiça, amor e a reconciliação. A justiça da esteira africana é comparada a justiça restaurativa que se encontra no manual Diálogo e Mediação de Conflitos nas Escolas-Guia Prática para Educadores segundo o Conselho Nacional do Ministério Público (2014).

A esteira no contexto africano é um espaço onde se dorme, onde se passa as refeições, onde se chora, onde se partilha a vida. Um espaço onde todos se sentem livres, a vontade, onde todos congregam juntos, procuram o bem-estar de outro. No caso de conflito 
em geral, o africano é chamado a sentar na esteira com a sua comunidade para encontrar soluções do conflito que afeta a comunidade. Razão pela qual o diálogo ressalta como elemento fundamental na resolução de conflitos. É nesta ótica de ideia que pode se pensar sobre a resolução de conflitos no contexto escolar em Moçambique.

Para que haja diálogo, precisa saber praticar e respeitar a justiça. No contexto africano, a mesma se pratica quando há abertura para outro, o reconhecimento do ato causado, com atitude de humildade e de partilha profunda na esteira sentado como comunidade. Contudo, a paz deveria ser um processo da vida inteira, um processo que não para pensando que a busca da paz já se realizou, quem pensa assim não é pacificador (MAZULA, 2015).

A esteira, no contexto africano tem, várias significações. Ela é um lugar propício de comunhão da comunidade onde todos os membros sentam-se e discutem sobre os fatos que divisem, originam conflitos. Lugar onde cada membro da mesma comunidade se preocupa e procura soluções para o bom andamento da vida social ou do grupo. No contexto africano, a esteira é um espaço de tomada de decisões e de reflexão. Os assuntos de conflitos levados na esteira são debatidos com calma, ponderação e juízo em relação aos convidados do invento e a atitude respeitosa neste momento crucial é o silêncio e cada um ocupe um espaço indicado na esteira para ouvir e escutar os sábios (MAZULA, 2015).

Na mesma perspectiva de Mazula (2015), as diferenças tratadas na esteira podem ser de natureza social ou familial, diferenças cujas consequências podem afetar toda a comunidade. Em relação aos conflitos escolares pode seguir a mesma linha de pensamento de Mazula. As pessoas envolvidas para resolver um conflito no contexto escolar, deve ser sábia pelo fato que todas pessoas não são consideradas como sábias na cultura bantus sublinha o mesmo autor. O reconhecimento do sábio é atribuído pela comunidade.

Os sábios para Mazula (2015) sabem proceder a escolha dos assuntos a tratar ou a debater e, eles organizam o tempo segundo os critérios de prioridade dependendo de cada caso a revolver. Em princípio os sábios têm uma grande experiência de vida, razão pela qual eles assumem o papel mediadores e conseguem resolver caso de conflito que afeta uma família. São eles que devem analisar o assunto colocado, investigam com rigor as causas do conflito, levam as partes envolvidas em conflitos a dialogar e a se entender, evitando lesar nenhuma das partes, fundamentam a mediação na construção da confiança mutua e suficiente para garantir que a conclusão dos bons ofícios seja imparcial para ambas partes.

Como referem Morin e Viveret (2011), que no contexto de conflito, os nomeados mediadores são movidos pelo princípio da esperança e também pela ética da pacificação. 
Nesta perspectiva, o princípio da esperança alimenta o diálogo entre as partes e a própria "complexidade favorece a ação porque ela nos dá a medida dos verdadeiros riscos e das verdadeiras possibilidades" (p. 24). Neste sentido as escolas moçambicanas podem ser um reflexo de serenidade e rigor, mas também, um espaço desta esteira africana onde são convidados os membros da comunidade escolar sentar-se para dialogar e resolver as suas diferenças.

Esta linha de pensamento sobre a esteira africana não pode ser uma oportunidade de gerir e resolver os conflitos escolares em Moçambique? A constituição do espaço "esteira africana" não pode constituir um lugar mediação de conflitos escolares? Porque não formar a juventude com alguns valores africanos da pertença a comunidade e na resolução de conflito no contexto da esteira africana?

\subsection{Conflito}

Segundo o Dicionário infopédia da Língua Portuguesa (2018), o conflito significa: "disputa violenta; combate, luta; enfrentamento entre elementos contrários ou incompatíveis; antagonismo; oposição; hostilidade beligerante; guerra; altercação; briga; discussão;...". Neste sentido o significado de conflito pode se entender como algo que divide, provoca choque, um descontentamento entre duas partes, algo de anormal na relação entre pessoas partilhando a mesma comunidade.

Alguns autores referem-se ao conflito de forma negativa, associando-o a uma ideia pejorativa de perigo, sendo o conflito necessário numa sociedade em termos de surgimento, pelo fato que ele é algo de positivo para estimular a inovação e criatividade dos comportamentos e das atitudes de cada pessoa que vive na comunidade. Para que haja um conflito precisa-se que cada uma das partes compreende a situação, depois que exista alguma forma de oposição e incompatibilidade, e para terminar que ocorra uma forma de interação entre as partes (FERREIRA; NEVES; CAETANO, 2011).

Vallejo e Guillén (2010) defendem o conflito como uma ocasião que ajuda os profissionais em pensar sobre o sentido do trabalho, criando novas inovações nas relações entre diferentes membros da comunidade, facilitando o entendimento, compreensão entre eles e construindo valores conjuntos em equipa.

Chrispino (2007) enfatiza que o conflito pode ser considerado como o bem-estar social, comunitário e isto pode trazer mudanças positivas, gerindo de maneira adequada, o modo de se inter-relacionar em base de coordenação que pode ajudar a comunidade a solucionar as suas diferenças tendo em conta o interesse supremo da comunidade. Con- 
solidando esta atitude leva aos membros da comunidade a uma via de progresso e de maturidade comunitária.

Para Silva e Flores (2014) as relações interpessoais têm uma compreensão relativa ao surgimento de conflito na ENSF. O ser humano é dinâmico por essência, deste fato, tem capacidade a sua vida com o outro em qualquer circunstância mesmo no contexto escolar. Estas relações podem ajudar na construção de uma comunidade escolar pacifica e, criando comportamento ético e promocional em diferentes níveis sociais (COSTA; MATOS, 2007). Revele-se que apesar da naturalidade da ocorrência de conflitos, estes estão sempre associados a uma situação inapropriada da vida humana pelo fato de quebrar a harmonia no ritmo da coletividade (SILVA; FLORES, 2014).

Os mesmos autores enfatizam que as situações de conflito são suscetíveis nas relações interpessoais, e podem se acontecer em dois níveis, isto quer dizer que, há conflitos entre pares (nível horizontal) e existem também conflitos ao nível vertical que caracteriza o relacionamento conflituoso entre alunos e professores. A gestão de conflitos dentro do ambiente escolar é algo que a cada dia requer mais formação dos professores, coordenadores e gestores das instituições de ensino, de forma a entender, gerir e resolver de maneira apositiva aos conflitos que surgem cada vez com maior frequência.

Contudo, para Silva e Flores (2014) é preciso repensar a forma de lidar com os alunos e adotar modelos de gestão que sejam capazes de dar a resposta mais adequada. Ignorar a existência dos conflitos e deixar que a solução ocorra de forma espontânea certamente não é a melhor maneira. Os envolvidos resolvem com seus próprios métodos, resultando, em muitos casos, em diferentes níveis de agressão.

Para Silva e Flores (2014), as dificuldades na resolução dos conflitos no processo de ensino-aprendizagem se acentuam quando não há uma estratégia eficaz na avaliação, resolução e acompanhamento do conflito eventualmente instalado. Delegar aos professores que simplesmente resolvam em sala de aula não é a maneira mais adequada de lidar com as situações. Deve se procurar meios adequados e eficazes, caso ainda haja desavenças entre os alunos, senão o mesmo conflito pode persistir sem encontra soluções. Deste modo, os gestores devem ser notificados pelos professores sobre os problemas dentro de sala, buscando compreender a fundo as motivações do conflito.

Escrevendo o seu livro sobre a paz dos moçambicanos, Gonçalves (2014), o antigo Arcebispo da Arquidiocese da Beira, insiste sobre uma educação para a paz. O mesmo convida o ministério da educação a acrescentar às características dos moçambicanos que devem ser produzidos pelo sistema nacional de educação, a pessoa pacífica, tam- 
bém a escola deve educar homens e mulheres pacíficos; da mesma maneira, a impressa escrita e a literatura oral devem educar para a paz. A resolução dos conflitos depende da escolha de cada um. Para Ferreira, Neves e Caetano (2011) resolução de conflitos depende da função de uma multiplicidade de condicionantes, entre as quais se mostram a natureza do objeto da divergência, as diferentes características das partes e o tempo disponível.

A mediação como um dos métodos de resolução de conflitos oferece um palco propício para as partes envolvidas no conflito encontrar oportunidade apropriada para uma solução ideal e de respeito as suas divergências. Isto implica um diálogo sincero, honesto entre as partes envolvidas em conflitos (MORGADO; OLIVEIRA, 2009). Para Silva e Flores (2014), a resolução de conflitos não é uma tarefa fácil, ela exige muita concentração, paciência, imparcialidade e, sobretudo, a capacidade de escuta de ambas partes envolvidas em conflito para que cheguem ao um consenso comum que lhes permitem a viver em harmonia em comunidade.

Não se pode ignorar que situações de agressividade entre pares sempre tiveram lugar, sendo algumas consideradas, tradicionalmente, como experiências de aprendizagem necessárias da passagem à maturidade (COSTA, 2016). Ultimamente, os fenómenos do comportamento em risco ocorrem de forma mais visível e com maior intensidade.

Juste (2007) sublinha que escola tem um papel imprescindível na promoção de uma convivência entre diferentes membros da comunidade. Razão pela qual, as situações de conflito como a indisciplina ou a violência são mais visíveis, e provocam uma desarmonia de entro da comunidade escolar. Para Costa (2016), se os alunos não interiorizam regras de convivência pacífica e resolvem as suas diferenças de uma forma violenta, é a própria sociedade, na sua dimensão humana, que está a ser posta em causa. Neste contexto, "a escola tem, ela própria, de se assumir, reflexivamente, como um espaço problemático de relações sociais" (VIEIRA, 2012, p. 11).

Vieira (2011) refere que a vida escolar é feita na participação social e nas relações coletiva, aí onde a dinâmica social se desenvolve e onde se deve interagir. A vida em comum ensina-se dos outros, isto é, apreender a dialogar, a comunicar, a debater, a concordar ou discordar, a colocar-se no lugar do outro, a criar acordos comuns, a definir e prosseguir objetivos comuns, numa lógica de respeito mútuo, tolerância e de cooperação, passa então a ser assumido como uma das principais preocupações do processo ensino e aprendizagem da vida da escola (COSTA, 2016). 


\section{METODOLOGIA DE PESQUISA}

A nossa abordagem foi predominantemente qualitativa, pelo fato de se tratar de um estudo de caso: a análise do fenómeno de conflitos escolares na ENSF na cidade da Beira em Moçambique, incluindo o levantamento de diferentes turmas da $12^{\mathrm{a}}$ classe no espaço temporal entre 2015-2016. Pretendíamos identificar com este estudo de caso aspetos como: o significado dos conflitos escolares no ambiente de estudo, tal como interpretado/ percebido pelos diferentes elementos da escola e frequência de observação dessas situações no quotidiano; elementos mais envolvidos em conflitos escolares; fontes de conflitos mais evidentes e quais os elementos que, no ambiente de estudo, mais instigam situações controversas; níveis de conflitos mais evidentes e quais são os departamentos de gestão de conflitos escolares; se a escola em estudo utilizam métodos diversos de solução de conflitos.

Para alcançar os objetivos do estudo pretendeu-se verificar se, do ponto de vista dos elementos da comunidade envolvida na pesquisa, o método da mediação é uma ferramenta de resolução de conflitos escolares. Tratou-se de um estudo exploratório, na linha da investigação-ação, transversal e com características qualitativas e quantitativas. Para a elaboração do estudo, recorreu-se também à pesquisa bibliográfica e a análise de conteúdo.

A etapa da análise dos dados procedeu se da seguinte forma: na pesquisa qualitativa (entrevista com os Educadores), em primeiro lugar, utilizou-se a transcrição e tabulação dos dados, manualmente, gravação, em seguida, foi se concebida com o suporte do programa Excel e analisados através do Software Statistical Package for Social Sciences (SPSS). A partir daí, elaborou-se as figuras das respostas dos elementos da ENSF.

Durante a recolha de dados a metodologia consistiu-se na apresentação de métodos quantitativa e de análise qualitativa onde participaram ou colaboraram alguns atores em estudo. A análise quantitativa foi feita através dos resultados de um inquérito por questionário, sobre a mediação como método alternativo de resolução de conflitos escolares aos alunos de $12^{\mathrm{a}}$ classe da mesma escola.

Esta seleção justifica se pelo facto da idade que podem ajudarem na resolução de conflitos entre os pares. Para dizer que no contexto africano, em geral, e moçambicano em particular, o "mais velho" tem muita influência sobre o "mais novo" neste contexto de mediação e resolução de conflitos. Este aspeto é muito importante no contexto africano.

A análise qualitativa foi feita na realização de entrevistas com os Educadores das escolas, pela sua posição ou responsabilidades, conhecem a área da pesquisa, como o caso de membros da direção e professores. Os objetivos das entrevistas respondem aos 
objetivos específicos. A análise qualitativa se difere do quantitativo como sublinham Lakatos e Marconi (2017).

Na perspectiva qualitativa, Coimbra e Martins (2013) entendem como um estudo de fenómenos sociais que implica a interação de comportamentos e atitudes na relação entre os pares. Trata se compreender o significado destes mesmos fenómenos sociais, integrando as dimensões (ALMEIDA; FREIRE, 1997). A curiosidade da pesquisa no contexto da educação procura informações sobre fenómenos sociais que ajuda a partilhar com a comunidade científica. Almeida e Freire (1997) referem que "(...) o investigador em face da necessidade de mais informação sobre um dado problema ou de uma teoria compreensiva sobre o mesmo, parte dum conjunto parcial de dados para a elaboração de um resumo descritivo dos fenómenos observados" (p. 30).

De acordo com Dal-Farra e Lopes (2003), “a conjugação de elementos qualitativos e quantitativos possibilita ampliar a obtenção de resultados em abordagens investigativas, proporcionando ganhos relevantes para as pesquisas complexas realizadas no campo da Educação" (p. 67). O mesmo pensamento vai de acordo com Flick (2005) que sublinha que a combinação de uso de métodos e de dados é possível a vários níveis, nos planos de pesquisa e nas técnicas de pesquisa.

Para Amado (2013, p. 69), "essa combinação e complementaridade de métodos e, sobretudo, de paradigmas, sustenta se sobre a nova visão que o paradigma da complexidade trouxe a luz do dia". Na abordagem quantitativa, fez-se uso de questionários. Para Lakatos e Marconi (2007), o questionário é "um instrumento de coleta de dados, constituído por uma serie ordenada de perguntas, que devem ser respondidas por escrito e sem a presença do entrevistador" (p. 203). Neste contexto (questionários aos alunos) realizou-se a tabulação dos dados, também manualmente, incluindo-se os resultados no programa Excel e analisados através do Software Statistical Package for Social Sciences (SPSS) que vai gerar os gráficos e tabelas. As tabelas geridas são o resultado de cruzamento de dados que tinha com base de género comparando com cada pergunta.

Procurou se nesta pesquisa mostrar a maneira como as partes envolvidas devem colaborar ativamente no projeto de mediação como método de resolução de conflitos e, perceber que a participação das mesmas partes beneficia de uma maneira ou outra do mesmo projeto. Desta forma, a metodologia desta pesquisa foi baseada em métodos mistos, com prevalência da metodologia qualitativa (COSTA, 2016).

Para Costa (2016), este estudo reveste um caráter hermenêutico, a mediação sendo uma experiência humana pela sua interpretação. De acordo com Stake (2009, apud COS- 
TA, 2016) "existem muitas, muitas formas de realizar estudos de caso" (p. 165). Optou-se nesta pesquisa o estudo de caso instrumental e avaliativo (Costa, 2016). O mesmo autor constata que as duas vertentes decorrem tanto na necessidade de percepção de um fenómeno social, como da intenção de obter informação necessária que ajuíza o valor, julga os resultados e a efetividade de um projeto de uma intervenção inovador.

De acordo com Stake (2009, apud COSTA, 2016) pretende-se pelo estudo de caso instrumental aprofundar a boa compreensão de um tema que é objeto desta pesquisa, de outro lado, estudo de caso avaliativo produz uma descrição densa, esclarece significados porque são partes importante da avaliação (YIN, 2015). Neste contexto, o estudo avaliativo é entendido como um estudo aplicado de certas ações que mostram elementos para tomar decisões e determinam certos conhecimentos que ajudam para resolver os conflitos comunitários ou do grupo bem determinado (GODOY, 1995, apud COSTA, 2016).

Costa (2016) preocupa se em saber se o estudo não tem o caráter de generalização, questiona se a utilidade cientifica dos estudos de caso. O mesmo termo refere se a possibilidade para os resultados do estudo particular poderem ser aplicáveis a locais, sujeitos e situações diferente. Razão pela qual o autor se refere ao estudo realizado por Duarte (2008, apud COSTA, 2016, p. 166) enfatiza que a profundidade de estudo pode permitir "aprender muita coisa que é geral nos casos únicos (...) ou ilustrar circunstancias cruciais para os sistemas e organizações". Neste contexto, Campo, Fernandez e Grisaleña (2005, apud COSTA, 2016) argumentam que: "a técnica de estudo de casos não tem como objetivo estabelecer gerações, se não atomizar situações e analisar particularidades; na verdade, evidenciar questões concretas. Algumas evidencias podem extrapolar-se e podem ser transportadas a outras situações similares" (p. 166).

Para Coimbra e Martins (2013, p. 32), a opção pelo estudo de caso foi sustentada pela "intencionalidade de investigar uma realidade, situada no aqui e no agora das interações sociais" e para Costa (2016), esta opção pelo estudo de caso foi sustentada pela procura de compreender, de forma interpretativa, o projeto aplicado numa escola para promover a elaboração de asserções proposicionais que permitam maximizar o conhecimento útil para situações contextos similares.

A população, e a constituição deste estudo, analisa a ENSF na cidade da Beira, Província de Sofala em Moçambique. A ENSF é de grande dimensão, com número elevado de alunos e funcionários, pelo que considerou uma amostragem (GIL, 2008) representativa das características da população. O presente estudo está focado nos Professores e alunos de $12^{\mathrm{a}}$ classe. 
Tabela 1 - Formação base ou acadêmica.

\begin{tabular}{|c|c|c|}
\hline Instituição & Licenciado & Mestre \\
\hline ENSF & E1, E3. E3-E18 & E2, E6 \\
\hline
\end{tabular}

Fonte: Elaborada pelos autores

A estrutura do funcionamento da ENSF em pesquisa pode se apresentar da seguinte maneira: um Diretor da escola, dois Diretores Adjuntos pedagógicos, um Administrador.

Tabela 2 - Cargo ocupado pelos entrevistados.

\begin{tabular}{|c|c|c|}
\hline Instituição & Entrevistado & Responsabilidade \\
\hline ENSF & E1-E5 & Membros de Direção \\
\hline ENSF & E6-E19 & Professores \\
\hline
\end{tabular}

Fonte: Elaborada pelos autores

A amostra consiste num total de 20 entrevistados educadores e funcionários desta escola, dos quais 19 responderam positivamente. Em 2016, a Escola Nossa Senhora de Fátima tinha sete (7) turmas de $12^{a}$ de um total de 286 alunos, dos quais, 132 rapazes e 154 meninas. É com estes números conseguiu se um tamanho de amostra aleatório como foi explicado nesta pesquisa. Utilizando, como universo populacional, os educadores, funcionários e alunos que atuam como elementos desta comunidade escolar, nesta pesquisa qualitativa fez-se a amostragem por conveniência (MALHOTRA, 2001; ZIKMUND, 2006). A amostra consiste num total de 200 alunos da $12^{\mathrm{a}}$ classe e 20 entrevistados educadores e funcionários. Dos 200 alunos escolhidos para o inquérito responderam positivamente no inquérito.

As variáveis que se propõe aqui são qualitativas. Pensou se tratar as seguintes variáveis: Alunos, Professores, Membros de direção, núcleos dos estudantes, falta de diálogo, falta de comunicação, falta de justiça, não atender o que explicam os Professores, notas arbitrárias, descriminação, falta de material didático e metodologia de ensino, rivalidade entre diferentes grupos.

Nesta perspectiva, os objetivos estabelecidos desta pesquisa pretenderam alcançar os seguintes resultados: que a mediação pode contribuir na melhoria das relações sociais na ENSF, em geral e entre os pares em particular; uma formação adequada dos pares mediadores na gestão de conflitos escolares gerindo uma certa abertura de diálogo entre os pares e melhor compreensão dos valores da mediação como: a justiça, respeito mútuo entre pares, diálogo construtivo, uma certa cultura de paz, direitos humanos, saber ser e saber 
estar; estes valores podem contribuir na redução da violência escolar, implementação de projeto de resolução de conflitos por meio da capacitação permanente.

\section{INTERPRETAÇÃO DAS RESPOSTAS OBTIDAS NAS ENTREVISTAS}

\subsection{Inquérito com alunos}

A escolha desta ENSF foi pelo fato do seu papel na formação da juventude na cidade da Beira. O ambiente de trabalho nesta escola foi interessante. Sendo uma escola privada católica, a sua estrutura é impecável para os serviços prestados na formação da juventude. Encontrou se um bom acolhimento, que se encaixou no ritmo normal do seu funcionamento sem incomodar o ritmo normal do trabalho. Trabalhou-se durante 1 mes para conseguir o resultado de dados coletados que são apresentados nas gráficas. Dos 200 inquiridos desta escola, todos reponderam positivamente ao inquérito. Notou se uma participação ativa do género feminino com $55 \%$ dos participantes e, $45 \%$ do género masculino. Para dizer que na ENSF, o género feminino predomina nestas turmas onde realizou se o inquérito.

A questão relativa ao que provoca o conflito em contexto escolar, focada na preocupação de saber, se a falta de diálogo e de respeito provoca o conflito escolar, se observa na figura 1. De todos que responderam, 75,5\% concordam que realmente, a falta de respeito e de diálogo provocam conflito escolar, 10\% descordam e 14,5\% não têm opinião. A tendência de resposta a esta pergunta mostra, claramente que, o diálogo e o respeito são elementos básicos para o relacionamento humano, sobretudo, nos convívios. Todos atores da educação são chamados a cultivar estes dois aspectos que são fundamentais para conseguir uma boa formação escolar. Cultivar o diálogo e o respeito não seria um bom caminho para uma paz verdadeira no ambiente escolar. Não há diálogo verdadeiro sem respeito.

Figura 1 - Percepção sobre a falta de respeito e de diálogo gera o conflito em contexto escolar

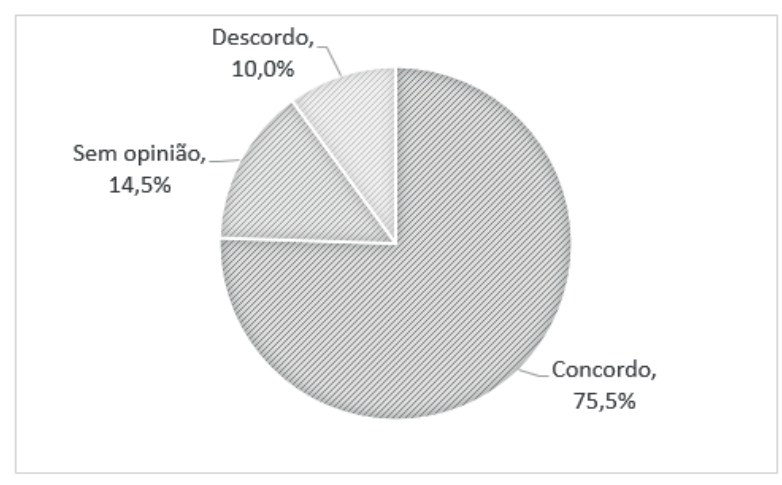

Fonte: Elaborada pelos autores 
O diálogo é uma ferramenta eficiente e construtiva para escolas superarem os obstáculos mais difíceis, para proporcionar ações colaborativas entre os educadores e os pares, sobretudo, para resolver os conflitos de forma simples e fácil. A construção de um bom diálogo é a principal ferramenta para se lidar com os conflitos. Diálogo é troca de entendimento e quem o inicia deverá procurar o retorno da outra pessoa para saber se a mensagem foi recebida e compreendida. $O$ resultado desta figura número 1 apresenta a importância fundamental do diálogo e respeito.

Os dados analisados na figura 2 apresenta que, $82 \%$ dos alunos concordam que os conflitos ocorrem em meio escolar quando as regras estabelecidas não são respeitadas, $8,5 \%$ descordam e 9.5\% sem opinião. De fato, toda organização humana necessita de estrutura, de regras e leis que regem para harmonizar o bom funcionamento da mesma. $O$ não respeito as regras estabelecida provoca constrangimento e frustração do grupo. A pergunta fundamental é que tipo de regras que precisa respeitar? Nos encontros informais, os inqueridos evocaram o caso do atraso na escola é um motivo de conflito. O resultado sobre esta questão chama atenção sobre a violação das regras estabelecidas. Os inqueridos são bem conscientizados a respeitar regulamento interno da escola. Eles percebem a importância dos compromissos que cada um deve assumir na escola para um bom sucesso nos estudos. Uma educação com respeito de regras estabelecidas faz do aluno uma pessoa mais preparada dentro e fora de sala de aula. Da mesma forma que existem regras familiares, também tem as escolas, trabalhista, enfim, regras sociais.

Figura 2 - Percepção sobre o conflito que ocorre em meio escolar quando as regras estabelecidas não são respeitadas.

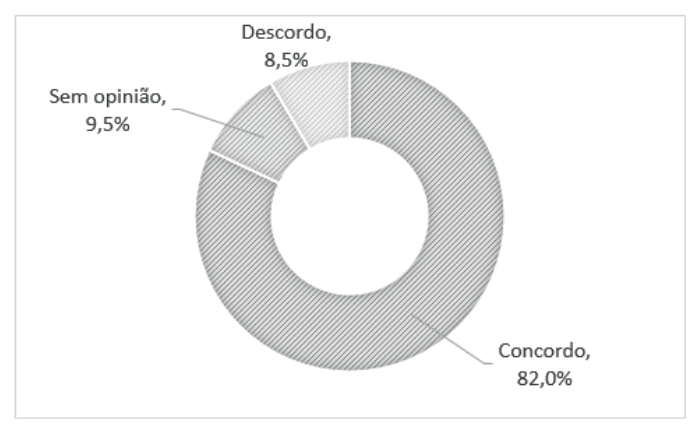

Fonte: Elaborada pelos autores

Os dados da figura 3 representam que, $40 \%$ dos inqueridos concordam que a desmotivação perante a escola por parte dos professores leva a conflitos entre alunos-professores, $24 \%$ dos inqueridos não concordam e $36 \%$ dos alunos inqueridos não têm opinião 
sobre a questão. Despertar a motivação dos alunos é imprescindível da parte dos professores. No cotidiano escolar, a desmotivação leva à falta de interesse, à desatenção, à inquietação e à frustração por grande parte dos alunos. Talvez, para uma aproximação mais estreita com a realidade vivenciada na escola, e com os alunos, seria interessante ter também o olhar dos próprios alunos e escutá-los.

Figura 3 - Percepção sobre desmotivação perante a escola por parte dos professores leva a conflitos entre alunos - professores.

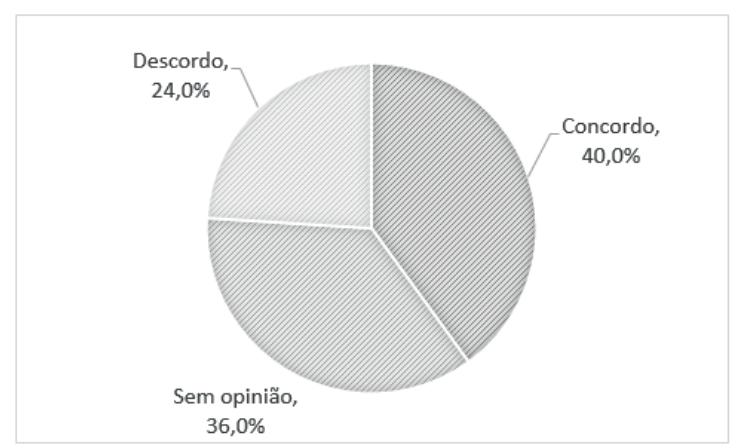

Fonte: Elaborada pelos autores

A partir da escuta entre professores e alunos pode se descobrir os elementos que mobilizam a aprendizagem e o estar na escola. Sendo assim, precisa se descobrir estratégias de ensino que os motivem para a aprendizagem. As metodologias de ensino precisam ser revistas e atualizadas de modo a atender às demandas dos novos cenários da educação contemporânea.

Em relação a desmotivação por parte dos alunos é provável que as respostas teriam sido diferentes e mais ricas em informação. Os dados desta figura 4 revelam que, $42,5 \%$ dos inqueridos concordam desta realidade da parte dos alunos, $29 \%$ sem opinião e $28,5 \%$ descordam.

Figura 4 - Percepção sobre desmotivação perante a escola por parte dos alunos provoca conflitos entre professores - alunos.

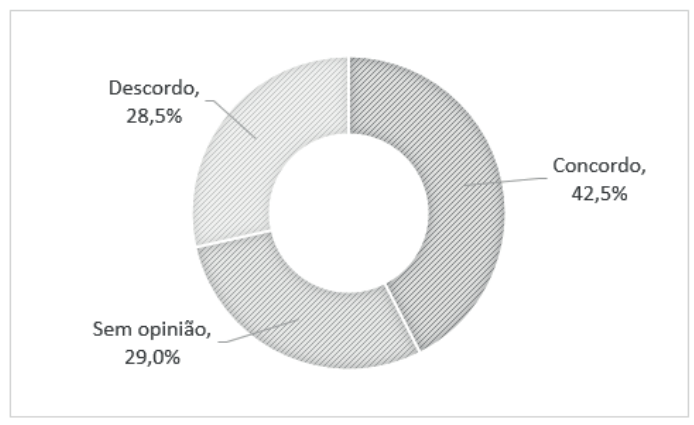

Fonte: Elaborada pelos autores 
Os resultados da pesquisa sobre os próprios contextos de atuação do professor podem contribuir para modificar as práticas de sala de aula e refletir sobre as mesmas. Ao escutar os alunos, poderemos compreender a situação, as causas da desmotivação e mudar a forma de ensino, confrontando e discutindo as informações com o grande grupo. Como já foi mencionado anteriormente, conhecer a realidade, o cotidiano dos alunos pode revelar muito da personalidade, da estrutura familiar e formação dos mesmos.

Outra vertente de desmotivação dos alunos é quando as práticas de avaliações antiquadas têm provocado desmotivações, mágoas pelas constantes reprovações e conflitos com professores. Se a escola não consegue envolver o aluno, o estudo acaba tornando-se uma obrigação necessária, que ele apenas suporta.

Uma vez que as metodologias de ensino e aprendizagem são em causas, o valor da educação pode ser em causa também. Nesta escola e segundo o resultado da figura 5 mostra que, $70,5 \%$ dos alunos concordam que as metodologias de ensino são muitas vezes contestadas pelos alunos e geram conflitos, $22 \%$ descordam e $7.5 \%$ sem opinião. Esta questão chama muita atenção na ENSF. Pelo fato de constatar que uma grande percentagem de alunos coloca em causa as metodologias de ensino.

Figura 5 - Percepção si os professores utilizam metodologias de ensino que muitas vezes são contestadas pelos alunos.

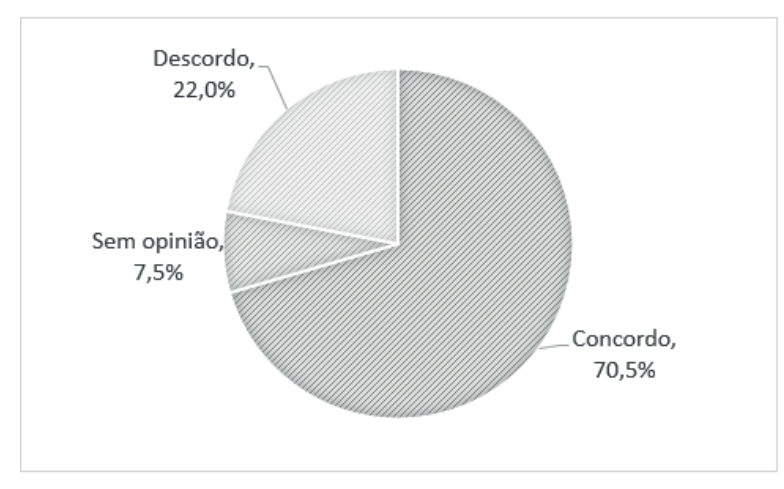

Fonte: Elaborada pelos autores

Atualmente muitos educadores procuram entender e responder aos desafios da educação considerando somente os elementos da contemporaneidade. Numa época de crises e transformações não só nas esferas políticas e sociais como também nas científica e pedagógica, os processos de ensino objetivam viabilizar a aprendizagem a todos. Nos encontros informais com os alunos desta escola houve se comentários como "este professor não sabe dar aulas" ou aquele aí faz só apontamento sem explicar nada... não gosto deste professor porque não entendo o que ele explica..." A multiplicidade de 
sujeitos, saberes, espaços e tempos não pode ser banalizada nas práticas escolares. A educação deve tomar conta de todos parâmetros da sociedade e sobretudo não minimizar outros contextos. Sabe-se que a compreensão dos processos educativos, de maneira crítica e sistemática, exige o reconhecimento das relações existentes entre educação, sociedade e teorias pedagógicas. Isto que foi percebido durante este momento de pesquisa.

Os processos educativos em Moçambique são produtos de transformações econômicas, políticas, científicas e tecnológicas. Portanto, a educação, enquanto uma expressão e resposta a essas transformações, precisa ser analisada a partir dos desafios que se encontra na sala de aula com alunos, pois muito do que se faz hoje nas escolas tem origem em teorias pedagógicas clássicas, certas vezes desconhecidas pelos próprios educadores. A própria escola aqui referida poderá pensar nesta questão e averiguar se realmente o resultado desta questão corresponde à realidade.

A figura 6 indica que, $44 \%$ dos inqueridos sentem se dificuldade em dirigir se aos professores para apresentar os seus problemas, $40 \%$ descordaram e $16 \%$ sem opinião. Deste modo, pode se observar que os inqueridos são prejudicados pelo fato de ter dificuldade se abrir com os professores em caso de lacuna. Se for isto o caso, como formar alunos com receio de se dirigir aos professores em caso de dificuldades? No processo de ensino e aprendizagem, o aluno deve se sentir à vontade de colocar as suas lacunas ao professor pelo fato de saber que o professor está em frente para lhe ajudar a perceber e aprender o que ele precisa. Professor é o seu orientador ou conselheiro.

Figura 6 - Os alunos têm dificuldades em dirigir-se aos professores para apresentar os seus problemas.

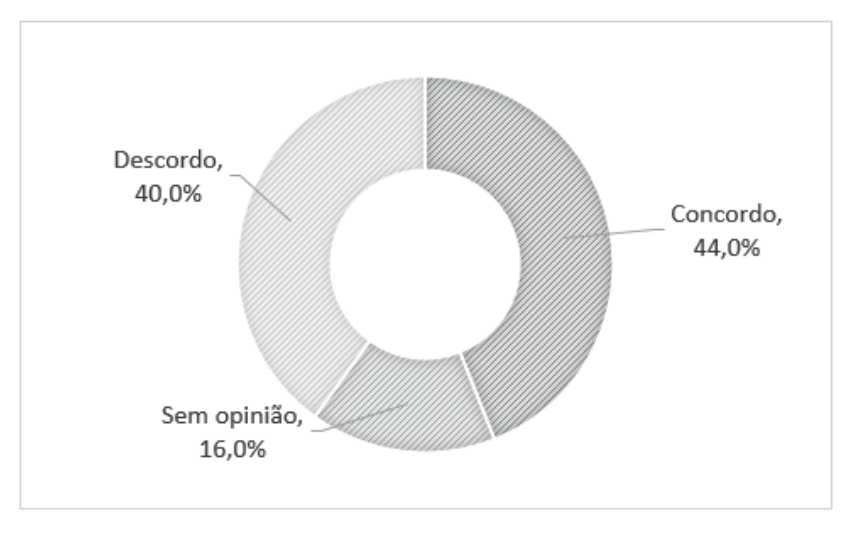

Fonte: Elaborada pelos autores

Sabe-se que o fracasso escolar aparece em Moçambique entre os problemas do próprio sistema educacional mais discutido, provavelmente, devido ao fato de que frequente- 
mente, os professores se deparam com alunos que apresentam dificuldades para aprender os conteúdos propostos no contexto escolar. Nestas ocasiões, muitas vezes, os professores não sabem como agir para auxiliar seus alunos na superação de suas dificuldades. Não se pretendeu aqui a pretensão de solucionar esta questão, mas apresentar uma análise que contribua para compreensão do fenômeno dificuldades de aprendizagem relacionadas ao aluno apresentar suas dificuldades ao professor.

A figura 7 apresenta o resultado da questão de maneira seguinte: $55 \%$ dos inqueridos descordam desta afirmação se não entende a explicação dos professores prejudica os alunos e gera conflitos, $24 \%$ concordam e $21 \%$ descordam. Constata se nesta questão uma certa disparidade de opinião verifica se nas respostas dos alunos. Nesta questão descobriu se a explicação dos professores pode prejudicar os alunos até o ponto de gerar conflitos.

Figura 7 - O aluno se sente prejudicado porque não entende a explicação do professor e gera conflitos com os professores.

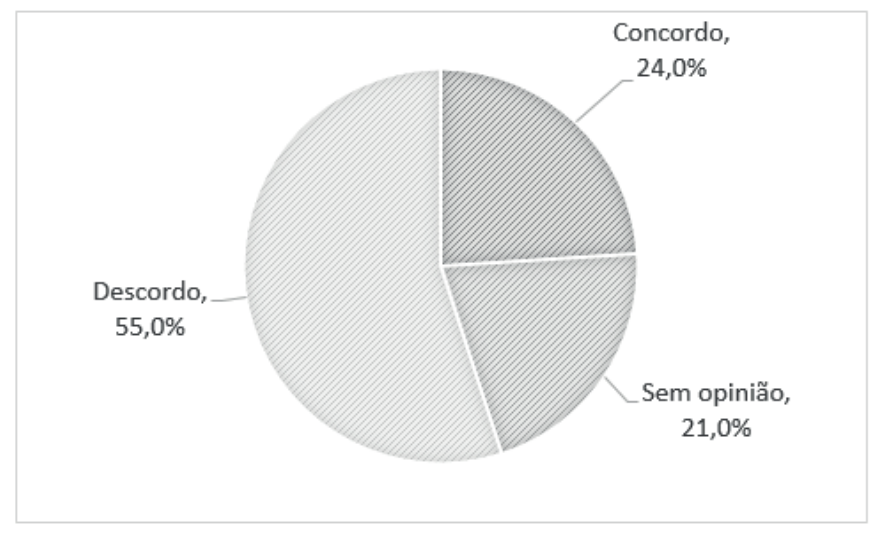

Fonte: Elaborada pelos autores

Trata se aqui de uma boa gestão da sala de aula. Ela é um fator essencial no processo de ensino aprendizagem. Uma aula bem gerida e sequenciada significa uma turma conquistada. Sabe-se que os professores fazem a diferença. Uma aula bem preparada, os temas, assuntos, bem sequenciados são fatores determinantes no sucesso da mesma e na supressão de problemas disciplinares. Se por um lado evitam problemas de stress do próprio professor, por outro lado evidenciam aulas mais fluídas e mais atraentes, porque melhor preparadas. Quando o professor fica bem preparado, a sua explicação durante aula atrai o aluno, o próprio aluno fica atento durante a explicação.

Os professores devem possuir uma boa formação académica e profissional para gerir a explicação na sala de aula. A diversidade de formação dos professores, 
a formação pessoal e profissional de cada professor com a sua história individual e pessoal, as suas expectativas, frustrações e desejos constituem fatores a considerar na explicação na sala de aula. Uma das questões fundamentais é: porque é que na aula de certos professores persistem mais problemas disciplinares do que na aula de outros professores?

No entanto como pode se ver na figura 8 as questões de notas arbitrárias prejudicam os alunos, deste fato gera conflitos; $41,5 \%$ concordam, $34,5 \%$ descordam e $24 \%$ sem opinião. A questão de notas é sensível para os alunos. Todos querem ter um bom resultado, no caso contrário, ninguém fica satisfeito. Neste aspeto surge a desconfiança. Os conflitos surgem pelo fato que a avaliação deve ter clareza, ser objetiva e diversificada com o objetivo de prever e de promover a aprendizagem dos alunos.

Figura 8 - Os alunos se sentem prejudicados porque o professor dá notas arbitrárias

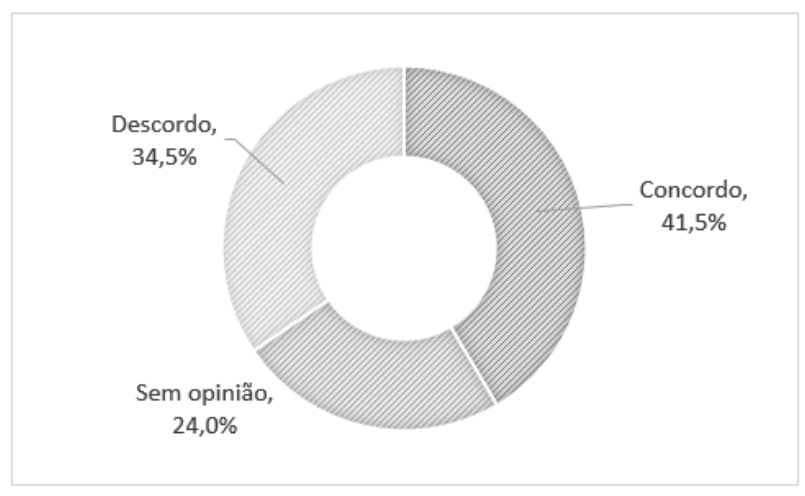

Fonte: Elaborada pelos autores

Muitas vezes a avaliação é utilizada com o objetivo diferente para prejudicar o aluno e não por sua função mais relevante, ou seja, avaliar se o aluno aprendeu. É óbvio constatar que a avaliação está relacionada diretamente à nota obtida. A prática de avaliação como sinônimo de medir saberes específicos, ainda é utilizada em muitos âmbitos escolares. Deste fato, o professor como avaliador deve ser imparcial e objetivo.

A questão sobre a discriminação apresenta muita preocupação da parte dos inqueridos. Os dados da figura 9 revelam que $52.5 \%$ concordam, $29 \%$ descordam e apenas $18.5 \%$ sem opinião. A discriminação está ligada aqui a certas atitudes que têm alguns professores e gestores da escola, por exemplo, o não respeito perante dos alunos, venda de notas, tirar aluno da sala de aulas sem motivo prévio, ofensas morais. Os alunos comentam entre eles e sabem categorizar alguns professores que se comportam mal perante de eles. 
Figura 9 - Os alunos se sentem prejudicados porque são discriminados.

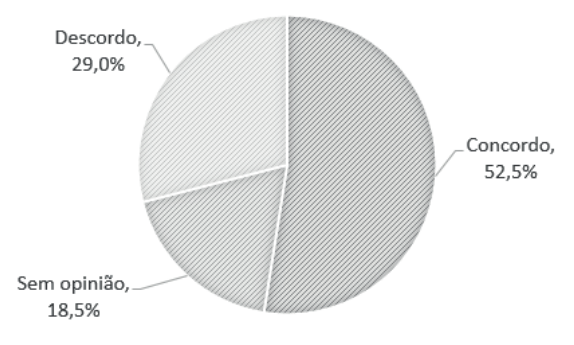

Fonte: Elaborada pelos autores

Os professores devem perceber que educação se constrói numa história de convivência, de forma que a maneira como se vive caracteriza o modo como se educa, ser justo e imparcial. Trabalhando nesta perspectiva, pode se tratar o aluno numa aceitação legítima na relação que constitui uma garantia de que o aluno irá aceitar-se a si mesmo, respeitar-se, aceitar e respeitar o outro. Não é difícil educar-se para a auto aceitação que leva à aceitação do outro. Basta que na interação o professor não negue, aceite e respeite o aluno como legítimo na relação. Esse ajuste da relação não é dado a priori, mas é construído na reflexão das ações produzidas na relação.

Segundo o resultado da pesquisa desta figura 10 onde $45 \%$ dos inqueridos concordam que os alunos se sentem prejudicados porque o professor faz avaliação inadequada, $27 \%$ descordam e $28 \%$ sem opinião. Esta questão está relacionada ao gráfico 12 onde foi referido as notas arbitrárias que dão alguns professores para prejudicar ao aluno. De fato, esta atitude não corresponde à imagem do professor. As avaliações inadequadas prejudicam realmente o aluno. As avaliações devem ser mais objetivas possível para ver o nível de compreensão do aluno.

Figura 10 - Os alunos se sentem prejudicados porque o professor faz avaliação inadequada.

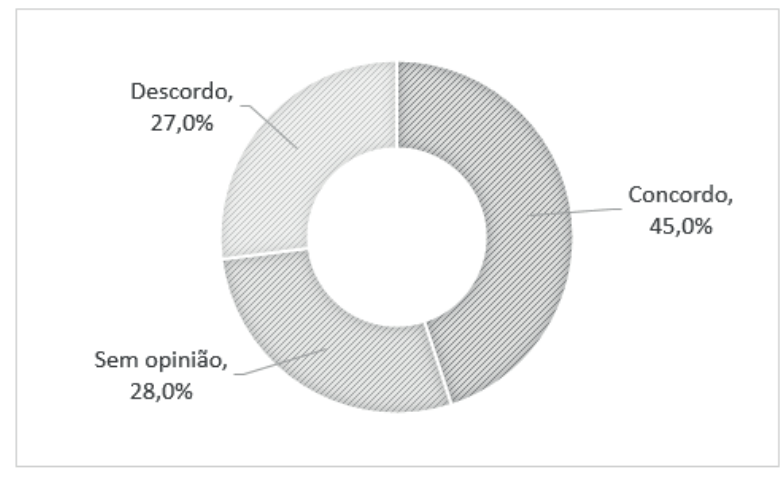

Fonte: Elaborada pelos autores 
Tem-se a impressão de que as aulas nunca são preparadas com antecedência por falta de empenho ou por pura negligência, são somente a experiência colocada a serviço dos alunos, de caráter dogmático e sem respeito às indagações dos alunos ou a seus conhecimentos, portanto; de forma abstrata. Freire $(2000$, p. 66) explica que "respeito à autonomia e à dignidade de cada um é um imperativo ético e não um favor que podemos ou não conceder uns aos outros".

Vale ressaltar que, com frequência, observam-se aulas que estão a serviço da motivação da classe. O que se vê é um abuso das aulas expositivas em detrimento de outras opções que sirvam de estímulo à curiosidade dos alunos e ao desejo de quererem saber cada vez mais.

Em relação ao mau comportamento dos alunos, os professores não gostam. O resultado da figura 11 mostra que, os inqueridos concordam com $45 \%$ contra $27 \%$ que descordam e $28 \%$ dos inqueridos ficaram sem opinião. O comportamento em risco dos alunos prejudica o próprio processo de ensino-aprendizagem dos mesmos alunos. A indisciplina é um fator importante deste comportamento inapropriado.

Figura 11 - As atitudes dos professores face ao mau comportamento dos alunos provocam conflito entre alunos - professores.

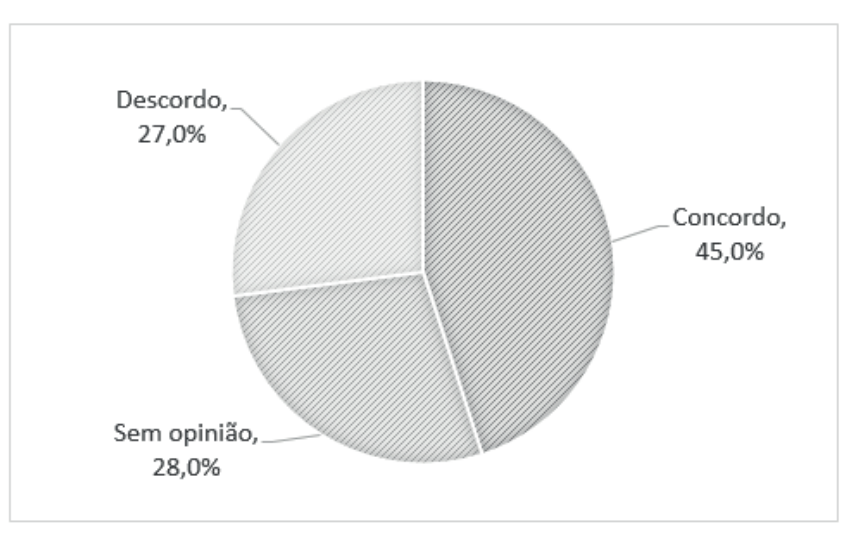

Fonte: Elaborada pelos autores

Incumprimento das regras da escola, isto é, o aluno não cumprir as regras da aula; fazer muito barulho, gritar, rir, falar alto na aula; intervir sem ser a sua vez; falarem todos ao mesmo tempo; levantar-se do lugar sem licença; mas também, quando o aluno não fazer os trabalhos de casa; não realizar as tarefas indicadas pelo professor; brincar na aula; não estar com atenção Comportamentos perturbadores da relação entre pares, isto é: falta de respeito; gozar com os colegas; não respeitar os colegas; distrair os colegas; não deixar as outras pessoas estar com atenção; discutir com o colega do lado. 


\subsection{Entrevistas com Educadores}

Na primeira pergunta analisou se a questão sobre "o significado de conflitos escolares". O objetivo foi de descobrir se o entrevistado percebe os conflitos escores de maneira geral. Várias respostas foram argumentadas. Nota-se que cada um dos entrevistados tem uma visão sobre o significado de conflitos escolares. Todavia, a questão pode se resumir como falta de entendimento entre diferentes atores educativos: professores, funcionários, entre os pares e encarregados da educação problemas que surgem dia a dia no processo de ensino-aprendizagem dentro da sala de aulas, entre alunos ou alunos-professores; divergência de ideias ou de interesses entre diferentes intervenientes.

Na segunda pergunta sobre "tipos de conflitos podem surgir na ENSF". Os tipos de conflitos encontrados nesta escola foram como: desobediência com professores, arrogância, falta de respeito com professores ou entre os pares; injustiça na atribuição de notas de perguntas abertas; brigas entre os pares diferentes culturas; agressões físicas e psicológicas; incumprimento dos deveres da parte dos alunos; âmbito social, questões didáticas; drogas, bebidas alcoólicas; falta de respeitos dos alunos, violência verbal e física; económico, social e religioso; mau comportamento da parte dos alunos.

As respostas encontradas na pergunta sobre "esses conflitos observam-se no dia-a-dia" são diversificadas. De facto, os tipos de conflitos são diversos, dependendo de grau de cada conflito. Para alguns a resposta foi afirmativa, mas não acontecem sempre, para outros são casos raros que acontecem no princípio do ano por causa de adaptação entre os pares.

A questão sobre as pessoas que participam quando os conflitos surgem em ambiente escolar são: Diretor da turma, Diretor Adjunto Pedagógico e Diretor da escola é o último interveniente no caso grave. Portanto a ENSF tem uma particularidade, existe nesta escola o que se chama a "Pastoral" um tipo de gabinete de resolução de conflitos não só para alunos, mas também para todos membros da comunidade escolar. O responsável da Pastoral faz parte dos intervenientes nos conflitos que surgem no ambiente escolar. A organização da ENSF tem a estrutura de uma escola privada católica, onde os princípios éticos são elementos fundamentais do comportamento de cada membro que pertence a esta comunidade escolar.

Respeitando os objetivos específicos da pesquisa, notou-se que as quatro primeiras perguntas responderam sobre a ocorrência de conflitos escolares na ENSF. Claro que não se pode identificar a ocorrência todos os conflitos escolares, mas pelo menos ter uma ideia sobre o acontecimento dos mesmos nesta escola. 
Uma outra curiosidade foi de descobrir as fontes de conflitos mais evidentes na ENSF. Tem várias fontes de conflitos como: o mau uso de telefones, mau uso de uniforme, violência física e verbal, drogas, álcool, estatuto social, barulho na sala de aulas, fraudes, indisciplina dos alunos, modo de vestir contrário ao regulamento interno da escola, falta de conduta moral por parte dos alunos e falta de paciência por parte dos professores, incompreensões, roubo o de material, abusos, insultos, desigualdades sociais e económicas...

Tratou se também a questão sobre os níveis de conflitos escolares. As reações podem ser violentas ou não violentas, quer dizer a conflitos latentes, percebidos, sentidos e manifestos em qualquer organização humana (NASCIMENTO; SAYED, 2011). Razão pela qual recorreu a uma explicação e reformulação da questão para uma melhor compreensão, ou seja, os entrevistados deveriam que escolher duas opções entre violento ou não violento. Evidenciou se que os níveis de conflitos não são violentos. Notou se que os níveis de conflitos são mais verbais, ofensas morais: a falta de respeito por parte de alunos, também a falta do diálogo. Neste sentido, os níveis de conflitos dependem da circunstância de cada conflito. O nível mais elevado acaba por violência física. Quando se trata de violência física, o nível de conflito é manifesto, momento em que a comunidade percebe que existe algo que não funciona entre uns determinados indivíduos da comunidade ou as partes.

A pergunta sobre os departamentos de gestão de conflitos escolares, e esta pergunta corresponde, justamente, ao objetivo específico 3, quer dizer, a maneira como é gerida os conflitos na ENSF. A escola tem: diretores de turmas, direção pedagógica, o próprio Diretor, Pastoral, comissão dos responsáveis da educação, também o núcleo dos alunos.

Outro elemento fundamental que tentou se saber é o papel do educador no processo da resolução de conflitos na escola. O papel do educador é: pacificar os conflitos, voz daqueles que não têm voz, vela pelo comportamento do seu educando, mediar e corrigir quando for necessário, conselheiro e mediador de conflitos, manter a ordem e tentar resolver de forma amigável e que todos lados saiam satisfeito, escutar ambas partes e tomar decisão, agente apaziguador dos conflitos, dialogar, reconciliar e acompanhar.

Quanto a sequência dos procedimentos para resolver um conflito, dependendo de caso, precisa conversar com os envolvidos, sensibilizar e informar os pais ou encarregados da educação. É preciso procurar resolver a partir do departamento mais próximo até o departamento do top, isto leva tempo. Depende de cada caso, precisa se ouvir os intervenientes, ponderar cada situação apresentada, emitir o seu juízo de valor, dar conselho final isento de emoções, pode se convocar as pessoas envolvidas no conflito e procura se, averiguar se situação. Se caso for delicado, envolve se mais pessoas quer dizer, envolver 
outros departamentos para encontrar uma saída. Outro interveniente disse que preconiza se em caso de conflito, é preciso ouvir, ponderar, aconselhar depois tomar medidas. Neste caso fica difícil determinar a sequência dos procedimentos para resolver um conflito. Existe conflitos que levam pouco tempo e outros podem custar para resolver.

Foi difícil responder corretamente à pergunta sobre situações de conflitos resolvidas nos anos 2015-2016. Pelo fato não ter um gabinete de resolução de conflitos torna se complicado ter um registo de conflitos deste período. Os entrevistados não se lembrem bem, para alguns não passaram cinco casos, dos quais três não foram resolvidos porque os pais complicaram a situação, e foram resolver no tribunal (casos extremos), para os outros evocam duas situações presenciadas, um grande número dos entrevistados não conseguiram determinar número de casos que aconteceu neste período.

Uma outra pergunta foi de conhecer o método utilizado para resolver os conflitos na ENSF. Preconiza se o diálogo e a mediação como método utilizado para resolver os conflitos escolares. Os entrevistados da mesma escola perceberam que a mediação ajuda muito para resolver os conflitos escolares. Neste sentido, esta pergunta corresponde á curiosidade ou a preocupação desta pesquisa e faz parte do último objetivo específico desta pesquisa.

Procurando saber os espaços específicos onde ocorrem mais frequentemente conflitos, os entrevistados concordaram que os conflitos ocorrem muitas vezes: na sala de aulas predomina outros os espaços específicos onde ocorrem mais frequentemente conflitos. Ficou claro que os alunos passam mais tempo na sala de aulas do que outros espaços como pátio, recintos da escola. Eles concordaram e insistiram sobre sala de aulas fica mais polémica em relação a outros espaços.

A preocupação de saber a melhor estratégia para resolver um conflito foi também uma das perguntas da pesquisa. Para uns, a melhor estratégia seria o diálogo, para outros pensam em sensibilizar, escutar, aconselhar, mostrar o caminho, conversar, acompanhar, cumprir com o regulamento interno da escola, mediar as partes envolvidas no conflito.

Sobre a forma mais correta para solucionar conflitos com os alunos ou entre alunos ficou claro para que é preciso acreditar ou dar confiança aos alunos, não repreender sempre, dar responsabilidade, dar uma formação continua que permite que eles gerem os conflitos entre os pares, que haja uma boa convivência, no diálogo entre eles, que tomem consciência da existência do conflito para encontrar solução.

Procurando saber da definição da mediação, os entrevistados explicaram dando um exemplo concreto do conselho dos pais e encarregados da educação envolvido no mesmo 
processo, isto implica uma mediação, quer dizer, uma forma de resolver os conflitos que possam surgir na comunidade escolar; apaziguar a situações de conflitos através de diálogo; chegar a um consenso entre as partes em conflitos, uma terceira pessoa se encarrega a fazer a mediação; procurar com os intervenientes de conflitos a solução do problema; resolver conflitos sem recorrer a violência; arbitrar no sentido que os elementos em conflitos tenham um entendimento para alcançar numa convivência saudável.

As respostas sobre a mediação como um dos métodos na gestão de conflitos escolares são afirmativas (89,4 educadores em favor e 10,6\% contra). Esta questão é fundamental para esta pesquisa porque responde ao objetivo da sugestão da mediação como um dos métodos alternativos de resolução de conflitos na ENSF.

Quanto a possibilidade da autonomia que a escola pode ter para desenvolver um processo de mediação é afirmativa, pelo fato mesmo de ter um regulamento interno que orienta o bom funcionamento da escola. O mesmo regulamento ajuda a escola a respeitar as regras estabelecidas no documento para garantir a disciplina na escola. Encontra se no mesmo documento os princípios éticos e morais que canalizam o bom senso e funcionamento da escola.

Os dados sobre a possibilidade da mediação entre alunos poderão constituir uma maneira de gestão de conflitos escolares foram interpelativos. Os entrevistados acharam que "sim" ela pode constituir uma forma de gestão alternativa de conflitos, mas o grande desafio é que os pares conseguem resolver as diferenças entre eles: festas, convívios... Esta questão deu uma abertura de pensar em mediação como um dos métodos alternativo na gestão e resolução de conflitos na ENSF.

A pergunta referente da capacidade que os alunos poderão ter de lidar convenientemente com os seus conflitos depende de tipo de conflito que pode surgir. A maioria dos entrevistados concorda que os alunos são capazes de lidar aos seus conflitos, mas a condição de ser formados como deve ser. A capacitação de eles fica ume pedra angular para formar uma equipe dos pares que poderá ajudar outros a resolver os seus problemas. O nosso desejo fica nesta linha de pensamento que pode contribuir na construção de uma cultura verdadeiramente de paz e de convívio entre os atores escolares. Notou se nas entrevistas que há falta neste sentido que os alunos tenham uma formação adequada para lidar com os seus conflitos, razão pela qual escolheu se uma amostra deliberada dos alunos

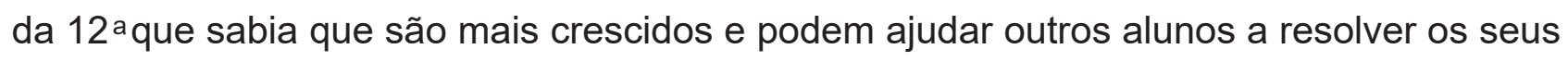
conflitos. Sublinhou se em África subsaariana que, o mais velho tem uma influência moral sobre o mais novo. Basta saber a maneira como funcionam as nossas culturas familiares para perceber esta linha de pensamento. Analisando estas entrevistas, pode se dizer que a constituição de um Departamento de Serviços de Apoio ao Aluno (DSAA) poderá ajudar 
a resolver os conflitos escolares de maneira simples e transparentes. Este departamento poderá ser considerado como ponto de referência dos alunos quando haver conflitos.

\section{DISCUSSÃO}

Pode se dizer que as entrevistas responderam a todos os objetivos específicos da pesquisa. Notou-se a existência de conflito nesta escola e, os mesmos conflitos são manifestos de várias maneiras como foi sublinhado nas respostas de entrevistas. A falta de motivação dos alunos pode ser considerada como um dos fatores para prosseguirem os seus estudos. Esta desmotivação pode ser causada por vários fatores: os pais que não valorizam os estudos dos filhos, falta de emprego, a poligamia, a pobreza dos de pais. Estes fatores causa um sentimento pejorativo nos filhos de não valorizar a escola.

Outro elemento importante que foi constatado nesta pesquisa é o desrespeito da parte de alunos aos dois níveis vertical e horizontal. O não respeito foi considerado nas entrevistas como um elemento catalisador do comportamento inapropriado e inaceitável para uma harmonia do grupo, nisto surge vários conflitos. Outros fatores que provocam conflitos são de ordem cultural ou religiosa.

Neste sentido, os educadores devem ter um papel mais importante no processo ensino- aprendizagem, o mesmo processo deve motivar os alunos para a escola, sensibilizando os, ensinando os a tomar consciência sobre a responsabilidade de cada um na sua integração na vida social de maneira digna. Os professores são chamados a educar os alunos, este trabalho exige uma dedicação total para conseguir uma formação integral, ou seja, uma formação humana e espiritual de cada aluno.

Cada professor tem um papel primordial na resolução de conflito na ENSF. Constatou se nesta escola que, os professores desempenham vários papéis na vida de dia-a-dia. Razão pela qual o processo de ensino e aprendizagem não é exclusiva, mas os professores são conselheiros, orientadores, educadores, mediadores, pois, são eles que conhecem a situação de cada aluno.

Razão pela qual a ENSF promove projeto de formação de líderes (professores e alunos) da comunidade escolar, no sentido de mediação para alcançar a mediação como um dos métodos alternativos na gestão e solução de conflitos escolares. Uma das funções do DSAA será de despistar e prevenir nas situações de conflitos através de uma resolução pacífica.

Assim, mediação não poderá se limitar só no seu aspeto de resolução de conflito, mas deverá ter uma olhada mais ampla que implica uma integração total na vida dos pares e, em qualquer circunstância. 
O DSAA deverá ser um espaço livre, lúdico, e de aprendizagem, um espaço onde o diálogo é a pedra angular, neutro, um espaço onde o aluno se senta em segurança e pode se expressar livremente, lugar onde os alunos se sentem à vontade, tal como mencionou um dos entrevistados: "os alunos às vezes têm medo, precisam dum espaço onde eles sentem um ambiente informal, onde ficam à vontade e também, falam livremente sobre determinada situação" (Entrevista realizada com Dr. António José Gonçalves, Diretor Adjunto Pedagógico da ENSF).

Os alunos ficam frustrados quando se trata de uma autoridade rígida. O que se quer propor é a criação de um espaço onde os alunos são responsáveis, onde eles se sentem valorizados, criativos, em conjunto com os gestores.

A grande maioria dos alunos desta escola valorizam o bom relacionamento em todos níveis, isto é, entre alunos e entre alunos e professores. Notou-se, que este bom relacionamento é mais frequente, principalmente, entre os alunos mais velhos, que estão na escola por mais tempo. Outros alunos consideram que existem muitos conflitos na escola e que muitas vezes se transformam em brigas violentas. Verificou-se que a maioria, raramente, se envolve com agressões físicas, pois quase a totalidade afirma nunca ter sofrido esse tipo de ocorrência.

Entretanto, são bem mais frequentes, as agressões verbais, como insultos, exposição ao ridículo com apelidos, difamação, rejeição e isolamento. Importante ressaltar que a maioria dos inqueridos relata que alguns desses casos ocorrem também entre professores e alunos e não somente entre eles. Segundo os alunos, o furto ou danificação de pertences também é frequente.

Complementando os dados sobre a percepção de aumento na incidência de conflitos, verificou-se que quase a metade dos alunos considera que a relação entre alunos e alguns professores é difícil. A proporção de alunos que relata ter sofrido agressão, mesmo que verbal, da parte do professor é significativa. As principais queixas de agressão perpetrada pelos professores consistem em ser insultado, discriminado, injustiçado, ridicularizado ou desprezado.

\section{CONCLUSÃO}

Começando para identificar a ocorrência de conflitos escolares na ENSF, os dados analisados na escola através de entrevistas realizadas aos Educadores revelaram que o conflito é inerente a vida humana e têm havido um aumento de situações de conflitos escolares e a origem desses conflitos está ligada a violência como fator que determina a exclu- 
são escolar, caso de jovens vulneráveis, a pobreza dos pais, falta de emprego dos pais e por outras situações económicas não financeiras favoráveis.

Contudo, esta situação de conflito verifica se na SNSF por causa de sentimento de descriminação social por parte dos alunos que estão inseridos nesta escola, e reflete no de comportamento não desejável, reprovações, desmotivação, insucesso escolar, e acaba por violência entre os alunos. Neste sentido, a mediação escolar é um método que articula se em momento de diferenças entre membros da mesma comunidade, trazendo soluções adequadas nos conflitos das partes envolvidas. Deste fato, a importância do processo de mediação é de evitar que surgem e que tais conflitos permaneçam e que os mesmos se transformam em violência.

Apontar as fontes e os níveis de conflitos escolares na ENSF foi o segundo objetivo desta pesquisa. Constatou se neste objetivo que vários motivos são fontes dos conflitos escolares. Alguns merecem ser mencionados aqui: o comportamento não desejável de alguns alunos, ou seja, comportamento de risco, diferença cultural, religião, falta de compreensão, desonestidade e não cumprimento do regulamento interno. Notou-se que cada dado de análise completou outro.

Neste contexto, tais situações conflituosas devem ser geridas com tendências a criar um bom ambiente entre os membros da comunidade escolar, respeitando as diferenças e opinião de cada membro implicado neste processo de conflito. Em outras palavras, precisa-se constituir elementos de diálogo construtivo, sólido que permitem uma dinâmica e uma cooperação necessária para o interesse supremo ambiental da comunidade escolar.

O terceiro objetivo específico foi de descrever a maneira como são geridos os conflitos escolares na ENSF. Os resultados dos dados analisados revelaram que os conflitos entre os alunos são mais interpessoais, ou seja, conflitos que necessitam ser resolvidos pelas instâncias competentes. As mesmas instâncias capazes e flexíveis no atendimento cuidadoso dos intervenientes dos conflitos, facilitando um diálogo construtivo, transparente para uma resolução pacífica do conflito.

Assim, o último objetivo específico tratou-se de mediação como um dos métodos alternativos que são compreendidos de alguma forma pelos alunos abrangidos deste estudo. Sugeriu-se a mediação como um deles que pode ajudar a comunidade escolar da ENSF na resolução de conflitos escolares. Contudo, a maioria dos intervenientes nas entrevistas realizadas ao longo desta pesquisa, concordam que a mediação pode ser um dos métodos alternativos na resolução de conflitos escolares. Tendo em conta os dados analisados e refletindo-se sobre a pesquisa, notou se realmente que os intervenientes concordam que a mediação pelas suas caraterísticas poderá permitir ao aluno de valorizar e moderar as suas 
visões, principalmente, quando embasado pelo bom senso e construção de um ambiente saudável na comunidade escolar.

Razão pela qual precisa-se formar, capacitar os mediadores escolares adequados para auxiliar na resolução de conflitos, buscar através do diálogo vias de resolver pacificamente os conflitos das partes envolvidas.

Por isso, achou-se pertinente sugerir a criação do Departamento de Serviços de Apoio ao Aluno (DSAA) nesta escola moçambicana, onde os alunos podem encontrar um espaço propício de atendimento em qualquer momento. O tal espaço deve ser aberto em qualquer circunstância de conflitos escolares, uma maneira de evitar de tratar os conflitos escolares nas instâncias clássicas da escola.

Neste contexto, a mediação na resolução de conflitos poderá ser um fator estimulador do bem-estar social na ENSF para, melhorar a qualidade da congregação escolar, entendido que o conflito não é algo pejorativo nas relações humanas, mas algo positivo quando permite uma abertura das partes envolvidas no diálogo construtivo, sincero e honesto na harmonização cooperativa das relações comunitárias na escola.

A pesquisa revela o grau que os alunos serão capazes de aprender a dialogar, a coordenar, cooperar, a comunicar, vivendo em sociedade com harmonia, isto é, assumindo a maneira de congregar juntos, na construção de uma sociedade justa, de paz e de concordância.

\section{REFERÊNCIAS}

ALMEIDA, L. S., \& FREIRE, T. Metodologia da investigação em psicologia e educação (5. ${ }^{a}$ ed.). Braga: Psiquilibrios, 2017.

AMADO, J. Manual de investigação qualitativa em educação. Coimbra: Imprensa da Universidade de Coimbra, 2013.

CAMPO, A.; FERNÁNDEZ, A. \& GRISALEÑA, J. La convivencia en los centros de secundaria: un estudio de casos. Revista Iberoamericana de Educación, 38, 121-145. Disponível em http:// www.rieoei.org/rie38a07.pdf. Consultado em: 29 de Setembro de 2018. 2005, mayo-agosto.

CHRISPINO, Á. Gestão do conflito escolar: da classificação dos conflitos aos modelos de mediação. Revista Ensaio: Avaliação e Políticas Públicas em Educação [Online], v. 15, n. 54, pp. 11-28. 2007. 
COIMBRA, M., \& MARTINS, A. Case Studying Educational Research: A Way of Looking at Reality. American Journal of Educational Research, v. 1, n. 9, p. 391-395. 2013.

CORREIA, J. A., \& CARAMELO, J. A construção social e legislativa da mediação: Figuras e políticas [The social and legislative construction of mediation: Figures and policies]. In José Alberto Correia \& Ana Maria Costa e Silva (Orgs.), Mediação: (D)os contextos e (d)os actores (pp. 13-32). Porto: CIIE/Afrontamento. 2010.

CONSELHO NACIONAL DO MINISTÉRIO PÚBLICO. Diálogo e Mediação de Conflitos nas Escolas - Guia Prática para Educadores. Brasília: Gráfica e Editora Movimento. 2014.

COSTA, M. Mediação de conflitos: construção de um projeto de melhoria de escola. Tese de Doutoramento em Educação, Universidade Lusófona de Humanidades e Tecnologias de Lisboa, 2016.

COSTA, M., \& MATOS, P. Abordagem sistémica do conflito. Lisboa: Universidade Aberta, 2007.

DAL-FARRA, R., \& LOPES, P. Métodos mistos de pesquisa em educação: pressupostos teóricos. Nuances: Estudos sobre Educação, 24, 3, 67-80. Disponível em http://dx.doi. org/10.14572/nunaces.v24i3.2698. 2003. Consultado em: 29 de setembro de 2018.

DIAS, M. Mediação, cidadania e emancipação social - A experiência da implantação do Centro de Mediação e Cidadania da UFOP e outros ensaios. Belo Horizonte: Fórum, 2010.

DICIONÁRIO INFOPÉDIA DA LíNGUA PORTUGUESA [em linha]. Porto: Porto Editora, 2003-2018. Disponível em: https://www.infopedia.pt/dicionarios/lingua-portuguesa/conflito

FERREIRA, J. M.; NEVES, J., \& CAETANO, A. Manual de psicossociologia das organizações. Lisboa: Escolar Editora, 2011.

FREIRE, P. Pedagogia da autonomia (27 a . ed.). São Paulo: Paz e Terra, 2003.

GIL, A. Métodos e técnicas de pesquisa social (6. ${ }^{a}$ ed.). São Paulo: Atlas, 2008.

GODOY, A. S. Pesquisa qualitativa: tipos fundamentais. Revista de administração de empresas. v. 35, n. 3, São Paulo: mai./jun. p. 20-29. 1995.

GONÇALVES, J. A paz dos moçambicanos. Maputo: Layout \& Impressão, 2014.

JUSTE, R. Educación, ciudadanía y convivencia. Diversidad y sentido social da educación. Bordón, v. 59, n. 2-3, pp. 239-260. 2007.

MALHORTA, N., K. Pesquisa de marketing ( $3^{\text {a }}$ ed.). São Paulo: Bookman, 2001. 
MARCONI, M. \& LAKATOS, E. Metodologia Científica. $7^{\text {a }}$ ed. São Paulo: Atlas, 2017.

MAZULA, B. Na esteira da academia: razão, democracia e educaão. Maputo: Texto, 2008.

MAZULA, B. Desafios da universidade num momento de alegria e de crise. Revista Electrónica de Investigação e Desenvolvimento, v. 5, p. 61-76. 2015.

MORGADO, C., \& OLIVEIRA, I. Mediação em contexto escolar: transformar o conflito em oportunidade. Exedra: Revista Científica, v. 1, p. 43-56. 2009.

MORIN, E., \& VIVERET, P. Como Viver em Tempo de Crise? Trad. Carlos Correia Monteiro de Oliveira. Lisboa: Imprensa Nacional Casa da Moeda, 2011.

NASCIMENTO, E., \& SAYED, K. Administração de Conflitos. In Volume V - Gestão do Capital Humano, Coleção Gestão Empresarial - FAE Business School, Curitiba, Editora Gazeta do Povo, Cap. 4, 47-56. Acedido a 24 de Setembro de 2018 em: https://www.cairu. br/biblioteca/arquivos/Administracao/Gestao_do_Capital_Humano_FEA.pdf. 2002.

NEVES, T. Modelos de mediação social. In José Alberto Correia, \& Ana Maria Costa e Silva (Eds.), Mediação: (D)os contextos e (d)os actores (pp. 33-44). Porto: ClIE/Afrontamento, 2010.

SILVA, F., \& FLORES, P. O conflito em contexto escolar: transformar barreiras em oportunidade. In M. Carvalho, A. Loureiro \& C. Ferreira (org.). XII Congresso da Sociedade Portuguesa de Ciências da Educação, Ciências da Educação: espaços de investigação, reflexão e ação interdisciplinar (pp. 253-268). Vila Real: De Facto Editores. Em: http:// recipp.ipp.pt/bitstream/10400.22/6336/1/ART_PAulaFlores_2014.pdf. 2014.

STAKE, R. A arte da investigação com Estudos de Caso. 2. ${ }^{a}$ ed. Lisboa: Fundação Calouste Gulbenkian, 2009.

VALLEJO, R., \& GUILLEN, C. Mediación: proceso, tácticas y técnicas. $3 .^{a}$ ed. Madrid: Pirámide, 2010.

VIEIRA, A. Pedagogia social nas escolas: um olhar sobre a mediação e educação social. Cadernos de Pedagogia Social, v. 4, pp. 9-26, 2012.

VIEIRA, R. Educação e Diversidade Cultural. Notas de antropologia da educação. Portugal: Edições Afrontamento, 2011.

YIN, R. Estudo de caso: Planejamento e métodos (5. ${ }^{a}$ ed.). Porto Alegre: Bookman, 2015. ZIKMUND, W., G. Princípios da pesquisa de marketing (2. ${ }^{a}$ ed.). São Paulo: Thomsom, 2006. 